\title{
Pengaruh Penerapan Metode Guided Inquiry terhadap Aktivitas dan Hasil Belajar Biologi Siswa Kelas X SMA N 2 Banguntapan
}

\author{
H. B. A. Jayawardana \\ Fakultas Ilmu Pendidikan (FIP), IKIP PGRI Jember \\ Kampus I, Jln. Jawa No. I0 Jember, Jawa Timur, 68I2I, Indonesia \\ surat elektronik: hepta2011@gmail.com
}

\begin{abstract}
ABSTRAK
Penelitian ini bertujuan untuk (I) mengetahui pengaruh penerapan metode Guided Inquiry terhadap aktivitas belajar biologi pada materi avertebrata siswa kelas X SMA Negeri 2 Banguntapan. (2) mengetahui pengaruh penerapan metode Guided Inquiry terhadap hasil belajar biologi pada materi avertebrata siswa kelas X SMA Negeri 2 Banguntapan. Penelitian ini termasuk penelitian Quasi Experiment (eksperimen semu). Desain penelitian yang digunakan adalah Pretest-Posttest Control Group. Populasi penelitian adalah semua siswa kelas X SMA Negeri 2 Banguntapan. Sampel penelitian terdiri dari dua kelas yang diambil secara random (acak), yaitu kelas X2 sebagai kelas eksperimen dan kelas X3 sebagai kelas kontrol. Data penelitian berupa hasil observasi aktivitas belajar siswa dianalisis dengan uji $T_{w o}$ Independent Samples Kolmogorov-Smirnov dan data hasil belajar siswa berupa pretest dan posttest dianalisis menggunakan $t$-Test (uji-t) dengan bantuan program SPSS 17.0 for Windows. Hasil penelitian menunjukkan bahwa (I) terdapat pengaruh yang signifikan terhadap aktivitas belajar siswa pada kelas eksperimen dengan menerapkan metode Guided Inquiry dibandingkan dengan kelas kontrol yang menerapkan metode konvensional. Hal ini ditunjukkan dan dibuktikan dengan hasil uji Two Independent Samples Kolmogorov-Smirnov, dengan sig. (2-tailed) senilai 0,000 < taraf signifikansi (0,0I). (2) tidak terdapat pengaruh yang signifikan terhadap hasil belajar biologi pada kelas eksperimen dengan menerapkan metode Guided Inquiry dibandingkan dengan kelas kontrol. Hal ini ditunjukkan dan dibuktikan dengan hasil uji-t dengan sig. (2-tailed) senilai 0,3I8 > taraf signifikansi (0,05). Kesimpulan hasil analisis data menunjukkan bahwa metode Guided Inquiry berpengaruh signifikan terhadap aktivitas belajar, dan dapat pula meningkatkan hasil belajar siswa meskipun tidak secara signifikan, sehingga dapat digunakan sebagai salah satu alternatif metode pembelajaran biologi di sekolah.
\end{abstract}

Kata kunci: metode, guided inquiry, aktivitas belajar, hasil belajat

\section{Pendahuluan}

Pendidikan merupakan salah satu faktor penentu kualitas bangsa. Melalui pendidikan, generasi bangsa mempunyai bekal pengetahuan untuk menjadi individu yang mandiri dan berkualitas. Oleh sebab itu, inovasi dan pengembangan pendidikan nasional perlu dilakukan agar menghasilkan manusia Indonesia yang berkualitas, yang tidak hanya unggul dibidang ilmu pengetahuan dan teknologi saja tetapi juga memiliki moral dan spiritual yang baik pula.

Kualitas hasil belajar sangat tergantung dari proses pembelajaran, sehingga upaya perbaikan dan pengembangan terhadap situasi dan faktor yang terkait dalam pembelajaran tersebut mutlak harus dilakukan, terutama pada interaksi antara guru dengan siswa. Proses pembelajaran akan lebih bermakna jika interaksi guru dan siswa optimal, dimana siswa terlibat aktif dalam proses pembelajaran.

Guru sebaiknya selalu terbuka termasuk pada siswa untuk bersama-sama mempelajari sesuatu yang ingin diketahui. Dilain pihak, siswa bukanlah makhluk bodoh, siswa adalah manusia ciptaan Tuhan seperti halnya dengan guru. Hanya saja siswa belum berkembang setinggi gurunya, namun telah diberi potensi untuk itu, dan guru berkewajiban untuk mengembangkannya. Oleh karena itu, guru sebaiknya mengenal potensi-potensi yang dimiliki oleh siswa untuk dikembangkan. 
Potensi-potensi siswa dapat dikembangkan melalui penerapan metode pembelajaran yang baik. Metode pembelajaran adalah cara-cara pelaksanan daripada proses pengajaran atau soal bagaimana teknisnya suatu bahan pelajaran diberikan kepada siswa-siswanya di sekolah (Suryosubroto, 2009: I40). Seorang guru memerlukan seperangkat metode mengajar untuk melaksanakan suatu strategi belajar-mengajar. Strategi merupakan rencana kegiatan untuk mencapai sesuatu, sedangkan metode adalah cara untuk mencapai sesuatu. Dengan kata lain, metode digunakan untuk merealisasikan strategi yang sudah ditetapkan (Sanjaya, 2010: 147).

Metode yang digunakan haruslah bersifat interaktif, inspiratif, menyenangkan, menantang, menumbuhkan kreatifitas dan kemandirian siswa sesuai dengan kemampuannya. Penggunaan metode pembelajaran yang tepat akan meningkatkan kualitas hasil belajar siswa. Interaksi edukatif akan berjalan dengan baik apabila siswa terlibat aktif dalam proses pembelajaran tersebut. Oleh karena itu, suatu metode dikatakan baik apabila dapat menumbuhkan keaktifan siswa dalam proses pembelajaran (Sudjana, 1989: 76).

Menurut Paul B. Diedrich (Sardiman, 2010: IOI), aktivitas belajar siswa dapat dibagi menjadi delapan aspek yaitu: aktivitas penglihatan (visual activities), aktivitas berbicara (oral activities), aktivitas mendengarkan (listening activities), aktivitas menulis (writing activities), aktivitas menggambar (drawing activities), aktivitas gerak (motor activities), aktivitas mental (mental activities), dan aktivitas emosional (emotional activities).

Peran siswa di dalam proses pembelajaran adalah berusaha secara aktif untuk mengembangkan dirinya di bawah bimbingan guru. Kegiatan ini yang disebut sebagai kegiatan belajar. Guru hanya menciptakan situasi yang memaksimalkan kegiatan belajar siswa. Kegiatan pembelajaran mengalami kegagalan apabila kegiatan mengajar tidak menghasilkan kegiatan belajar. Oleh karena itu, fungsi belajar pada siswa sangat menentukan keberhasilan pembelajaran. Siswa bukanlah objek pembelajaran, karena sebagai manusia ia adalah subjek yang aktif dalam kegiatan pembelajaran (Gulo, 2008: 23).

Aktivitas berasal dari kata dasar "aktif" yang berarti giat; dinamis; atau bertenaga (KBBI, 20I0). Aktivitas belajar biologi dalam hal ini adalah kegiatan yang dilakukan siswa dalam proses pembelajaran biologi. Dalam proses pembelajaran, aktivitas merupakan prinsip yang sangat penting, karena pembelajaran tidak akan pernah ada tanpa adanya aktivitas belajar (Sardiman, 2010: 96). Sebagai rasionalitasnya hal ini juga mendapat pengakuan dari berbagai ahli pendidikan.

Metode pembelajaran yang dapat melibatkan keaktifan siswa adalah metode penemuan (discovery) atau penyelidikan (inquiry). Metode yang digunakan pada penelitian ini adalah metode inkuiri terbimbing (Guided Inquiry). Inkuiri yang dalam bahasa inggris "inquiry" mempunyai arti pertanyaan, pemeriksaan, atau penyelidikan. Metode Guided Inquiry berarti suatu kegiatan belajar yang melibatkan seluruh kemampuan siswa untuk mencari dan menyelidiki suatu permasalahan secara sistematis, logis, analitis, sehingga dengan bimbingan dari guru mereka dapat merumuskan sendiri penemuannya dengan penuh percaya diri (Gulo, 2008: 84-85).

Metode Guided Inquiry merupakan bagian dari kegiatan pembelajaran dengan pendekatan kontekstual. Pengetahuan dan keterampilan yang diperoleh siswa diharapkan bukan hanya dari hasil mengingat faktafakta, melainkan juga dari menemukan sendiri (Sagala, 2010: 89). Dalam prosesnya, siswa tidak hanya berperan sebagai penerima materi pelajaran dari guru, melainkan mereka berperan untuk menemukan sendiri inti dari materi pelajaran tersebut (Sanjaya, 2010: 197). Proses pembelajaran inkuiri meliputi lima langkah yaitu: merumuskan masalah, mengajukan hipotesis, mengumpulkan data, menguji hipotesis, dan menarik kesimpulan.

Ciri-ciri pembelajaran yang berhasil salah satunya dapat dilihat dari kadar aktivitas belajar siswa. Semakin tinggi aktivitas belajar siswa, maka semakin besar peluang berhasilnya pembelajaran (Sudjana, I989: 72). Namun, dalam realitanya guru masih mendominasi proses pembelajaran tersebut. Berdasarkan observasi yang dilakukan oleh peneliti di SMA N 2 Banguntapan, diketahui bahwa guru masih lebih berperan aktif dibandingkan siswa. Proses pembelajaran yang dilakukan di SMA N 2 Banguntapan cukup bevariasi yaitu dengan menggunakan metode diskusi informasi, praktikum, studi literature, dan presentasi. Akan tetapi dalam proses pembelajarannya masih banyak mengalami hambatan.

Hambatan yang dialami dalam proses pembelajaran di SMA N 2 Banguntapan adalah siswa kurang aktif, siswa malas membaca (lebih suka diceramahi), siswa sering melakukan hal-hal di luar pembelajaran (bermain HP), dan fasilitas pendukung pembelajaran kurang memadai. Siswa yang kurang aktif dan malas membaca memaksa guru untuk menggunakan metode ceramah dalam menyampaikan materi pembelajaran.

Siswa cenderung menjadi pasif karena hanya menerima pengetahuan dari ceramah guru saja, siswa kurang berkesempatan untuk mengembangkan kreatifitasnya, dan hal itu akan menimbulkan rasa bosan pada diri siswa. Rasa bosan yang berkepanjangan akan menurunkan motivasi belajar siswa, akibatnya siswa menjadi malas belajar sehingga hasil belajarnya rendah. Hal ini terbukti dengan nilai Ujian Tengah Semester (UTS) biologi pada semester satu tahun ajaran 2010/20II yang kurang memuaskan. Nilai rata-rata UTS tersebut masih dibawah Kriteria Ketuntasan Minimal (KKM) yang telah ditetapkan yakni 75. Ratarata nilai UTS untuk kelas XI yaitu 72,93; kelas X2 yaitu 69,I5; kelas X3 yaitu 59, 96; dan kelas X4 yaitu $61,59$. 
Melihat fenomena tersebut, perlu adanya inovasi dalam metode pembelajaran di sekolah. Salah satu cara yang lebih baik dan dapat mendorong siswa untuk lebih terlibat aktif dalam proses pembelajaran dan hasil belajarnya meningkat adalah melalui metode pembelajaran Guided Inquiry. Oleh karena itu peneliti bermaksud untuk mengetahui pengaruh penerapan metode pembelajaran Guided Inquiry terhadap aktivitas belajar siswa dan hasil belajar siswa.

\section{Metode Penelitian}

Penelitian ini dilaksanakan di SMA $\mathrm{N} 2$ Banguntapan Tahun Ajaran 2010/201 I. Populasi dalam penelitian ini adalah siswa kelas X Semester 2 SMA N 2 Banguntapan Tahun Ajaran 2010/20II, yang terdiri dari empat kelas yaitu XI, X2, X3, dan X4. Uji homogenitas populasi menggunakan program SPSS 17.0 for Windows. Sampel dalam penelitian ini diambil dengan teknik cluster random sampling, karena populasi tidak terdiri dari individu-individu, melainkan terdiri dari kelompok individu-individu atau cluster (Zuriah, 2006: I24).

Penelitian ini termasuk jenis penelitian eksperimen semu (quasi experiment). Quasi experiment digunakan karena pada penelitian ini mempunyai kelompok kontrol yang tidak sepenuhnya dapat dikendalikan oleh peneliti, mengingat subjek penelitian adalah manusia yang mempunyai pemikiran masing-masing. Dengan kata lain, penelitian jenis ini mempunyai kelompok kontrol tetapi tidak dapat sepenuhnya berfungsi untuk mengontrol pengaruh variabel-variabel dari luar (Sugiyono, 2010: II4).

Pada penelitian ini, siswa yang diperlakukan sebagai kelompok kontrol (control group) adalah kelompok siswa yang dikenai metode pembelajaran ceramah bervariasi, sedangkan siswa yang diperlakukan sebagai kelompok eksperimen (experimental group) adalah siswa yang dikenai metode pembelajaran inkuiri terbimbing (Guided Inquiry).

Penelitian ini menggunakan desain pretest-posttest control group (Sugiono, 2010: II2). Dalam desain ini terdapat dua kelas yang dipilih secara acak, kemudian diberi pretest untuk mengetahui kemampuan awal dan postest untuk mengetahui kemampuan akhir setelah siswa kelompok eksperimen diberikan perlakuan (treatment).

Instrumen pengambilan data menggunakan lembar observasi untuk mengukur aktivitas belajar siswa dan menggunakan soal-soal tes untuk mengukur hasil belajar siswa. Pengujian validitas lembar observasi menggunakan uji validitas isi (content validity) dan validitas konstruksi (construct validity). Untuk pengujian soal-soal tes dilanjutkan dengan dianalisis menggunakan program SPSS I7.0 for Windows dengan teknik korelasi product moment atau metode Pearson (Sudjana, 2009: I I4).

Data hasil observasi aktivitas belajar siswa dianalisis secara deskriptif dan inferensial. Analisis secara deskriptif dilakukan dengan cara menafsirkan data mentah yang diperoleh berupa angka kedalam persentase. Adapun rumus persentasenya menurut Anas Sudijono (2003: 404I) adalah:

$$
\mathrm{P}=\mathrm{F} / \mathrm{N} \times 100
$$

$$
\begin{aligned}
& \text { Keterangan: } \\
& \mathrm{P}: \text { : angka persentase } \\
& \mathrm{F} \text { : angka yang akan dicari persentasenya } \\
& \mathrm{N} \text { : jumlah frekuensi atau banyaknya individu }
\end{aligned}
$$

$$
\begin{aligned}
& \text { Kriteria : 8I-I00\% tinggi } \\
& \text { 6I-80\% cukup } \\
& 40-60 \% \text { kurang } \\
& <40 \% \text { rendah }
\end{aligned}
$$

Data aktivitas belajar siswa kemudian diolah secara inferensial menggunakan bantuan program SPSS I7.0 for Windows yaitu dengan uji Kolmogorov-Smirnov untuk mengetahui signifikansi aktivitas belajar siswa antara kelas eksperimen dengan kelas kontrol. Kriteria pengambilan keputusan berdasarkan nilai probabilitas, yaitu dengan membandingkan sig. (2-tailed) atau nilai probabilitas ( $\mathrm{p}$ ) dengan 0,05 , jika $\mathrm{p}<0,05$ berarti ada pengaruh yang signifikan penerapan metode guided inquiry terhadap aktivitas belajar siswa.

Uji normalitas data tes hasil belajar siswa menggunakan uji Chi-kuadrat (X2) dengan bantuan program SPSS 17.0 for Windows. Uji homogenitas dilakukan dengan menggunakan uji $\mathrm{F}$ menggunakan bantuan program SPSS I7.0 for Windows. Uji hipotesis pada penelitian ini menggunakan uji-t ( $t$-test) dengan program SPSS I7.0 for Windows. Uji-t dapat digunakan untuk menguji pengaruh satu variabel independen terhadap satu atau lebih variabel dependen (Trihendradi, 2009: III). Kriteria pengambilan keputusan berdasarkan nilai probabilitas, yaitu dengan membandingkan sig. (2tailed) atau nilai probabilitas ( $\mathrm{p}$ ) dengan 0,05 , jika $\mathrm{p}<$ 0,05 berarti ada pengaruh yang signifikan penerapan metode guided inquiry terhadap hasil belajar siswa.

\section{Hasil dan Pembahasan}

\section{A. Aktivitas Belajar Siswa}

Hasil penelitian menunjukkan bahwa kelas eskperimen mempunyai aktivitas dengan kategori yang cukup yaitu dengan frekuensi 23 (7I,87\%), sedangkan kelas kontrol mempunyai aktivitas dengan kategori kurang yaitu dengan frekuensi 20 (62,50\%). Hal ini terjadi karena pada kelas eksperimen diberi perlakuan yaitu dengan metode Guided Inquiry, dimana metode tersebut mendorong siswa untuk lebih aktif dalam kegiatan belajarnya. Data aktivitas belajar siswa secara lebih lengkap dapat dilihat pada tabel I dan gambar I berikut ini. 
Tabel I. Data Aktivitas Belajar Siswa Kelas Eksperimen dan Kelas Kontrol

\begin{tabular}{|c|c|c|c|c|}
\hline No. & Kategori & Skor & Eksperimen & Kontrol \\
\hline I. & Rendah & $\overline{\leq 40}$ & $0 \%$ & $31,25 \%$ \\
\hline 2. & Kurang & $4 I-60$ & $0 \%$ & $62,50 \%$ \\
\hline 3. & Cukup & $6 \mathrm{I}-80$ & 71,87\% & $3,125 \%$ \\
\hline 4. & Tinggi & $8 \mathrm{I}-\mathrm{I00}$ & $28,13 \%$ & $3,125 \%$ \\
\hline \multicolumn{3}{|c|}{ Total } & $100 \%$ & $100 \%$ \\
\hline
\end{tabular}

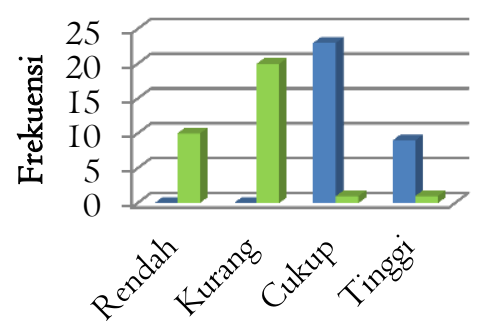

$\square$ Eksperimen

- Kontrol

\section{Kategori Aktivitas}

Gambar I. Diagram Perbedaan Data Aktivitas Antara

Kelas Eksperimen dengan Kelas Kontrol

Aktivitas belajar siswa dalam penelitian ini meliputi delapan aspek yang diamati. Data hasil penelitian terhadap delapan aspek tersebut dapat disajikan dalam tabel 2 dan gambar 2 seperti berikut ini.

Tabel 2. Data Aktivitas Siswa dari Berbagai Macam Aspek

\begin{tabular}{clrr}
\hline No. & $\begin{array}{c}\text { Aspek yang } \\
\text { Diamati }\end{array}$ & Eksperimen & Kontrol \\
\hline I. & Visual activities & $84,37 \%$ & $43,75 \%$ \\
2. & Oral activities & $93,75 \%$ & $6,25 \%$ \\
3. & Listening activities & $96,87 \%$ & $43,75 \%$ \\
4. & Writing acivities & $87,50 \%$ & $28,12 \%$ \\
5. & Drawing activities & $96,87 \%$ & $6,25 \%$ \\
6. & Motor activities & $93,75 \%$ & $21,87 \%$ \\
7. & Mental activities & $84,37 \%$ & $6,25 \%$ \\
8. & Emotional activities & $96,87 \%$ & $\mathrm{I} 5,62 \%$ \\
\hline
\end{tabular}

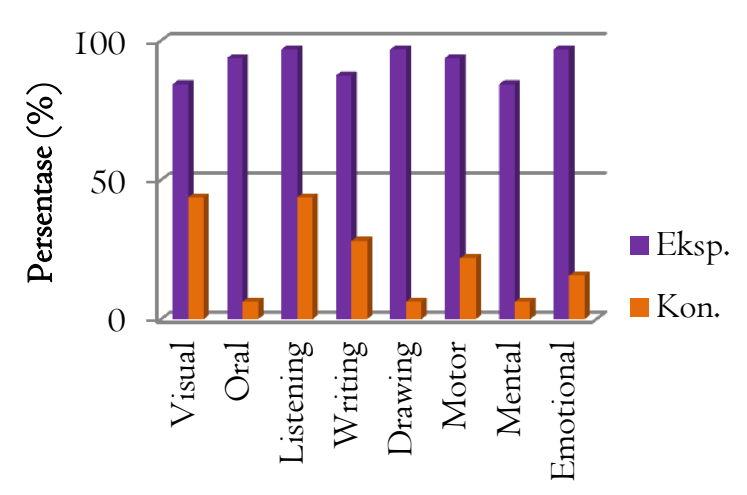

Kategori Aktivitas

Gambar 2. Diagram Data Aktivitas Siswa dari Berbagai Macam Aspek
Tabel 2 dan gambar 2 merupakan tabel dan diagram aktivitas belajar siswa pada kelas eksperimen dan kelas kontrol berdasarkan aspek-aspek yang diamati. Berdasarkan tabel dan diagram tersebut dapat diketahui bahwa aktivitas belajar pada kelas eksperimen lebih tinggi disemua aspek dibandingkan kelas kontrol. Aktivitas tertinggi pada kelas eksperimen mencapai 96, $87 \%$ dan terendah $84,37 \%$, sedangkan pada kelas kontrol aktivitas tertinggi hanya mencapai $43,75 \%$ dan terendah yaitu 6,25\%. Jadi, aktivitas belajar biologi pada kelas eksperimen jauh lebih tinggi dibandingkan pada kelas kontrol. Hal ini disebabkan oleh pengaruh penerapan metode Guided Inquiry pada kelas eksperimen, yang mendorong siswa untuk lebih aktif belajar.

Pada kelas eksperimen, semua aspek yang diamati mendapatkan nilai persentase yang tinggi (diatas $80 \%$ ), misalnya aspek visual activities yaitu 84, 37\% (27 siswa), motor activities 93, $75 \%$ (30 siswa), drawing activities $96,87 \%$ (3I siswa) dan emotional activities 96, 87\% (3I siswa). Hal itu membuktikan bahwa metode Guided Inquiry memberikan pengaruh yang sangat signifikan terhadap aktivitas belajar siswa. Siswa dapat dengan leluasa menggunakan kemampuan motorik, afektif, dan kemampuan berfikirnya dengan baik.

Hal senada pernah diungkapkan oleh Piaget, yang mengatakan bahwa seorang anak itu akan berfikir sepanjang Ia berbuat (beraktivitas), tanpa perbuatan maka anak tersebut tidak berfikir. Oleh karena itu, agar anak berfikir sendiri maka harus diberi kesempatan untuk berbuat sendiri. Dengan demikian, jelas bahwa aktivitas itu dalam arti luas, baik yang bersifat fisik maupun mental akan membuahkan aktivitas belajar yang optimal (Sardiman, 2010: 100).

W. Gulo (2008: 85) juga menyatakan bahwa metode Guided Inquity berarti suatu rangkaian kegiatan belajar yang melibatkan secara maksimal seluruh kemampuan siswa untuk mencari dan menyelidiki secara sistematis, kritis, logis, analitis, sehingga mereka dapat merumuskan sendiri penemuannya dengan penuh percaya diri. W. Gulo juga menyatakan bahwa sasaran utama pembelajaran menggunakan metode Guided Inquiry ini adalah:

I. Keterlibatan siswa secara maksimal dalam aktivitas belajarnya.

2. Terarahnya aktivitas belajar secara logis dan sistematis pada tujuan pembelajaran.

3. Mengembangkan sikap percaya diri (self believe) pada diri siswa tentang apa yang ditemukan dalam proses inkuiri.

Metode Guided Inquiry menekankan pada aktivitas belajar siswa. Hal itu sesuai dengan pendapat seorang pakar pendidikan lainnya yaitu Wina Sanjaya (2010, 196-197), Beliau menyatakan metode Guided Inquiry menekankan kepada aktivitas siswa secara maksimal untuk mencari dan menemukan, artinya metode tersebut menempatkan siswa sebagai subjek belajar. 
Pada kelas kontrol, terdapat aspek yang mendapatkan nilai persentase dengan kategori kurang $(<$ $40 \%)$ dan kategori rendah (40\%-60\%). Aspek yang mendapatkan kategori kurang misalnya drawing activities $6,25 \%$ ( 2 siswa), mental activities $6,25 \%(2$ siswa), dan motor activities $21,87 \%$ ( 7 siswa), sedangkan aspek yang mendapatkan kategori rendah misalnya visual activities dan listening activities yaitu $43,75 \%$ (I4 siswa). Kurang atau rendahnya aktivitas belajar pada kelas kontrol karena pengaruh metode pembelajaran yang digunakan yaitu ceramah disertai dengan diskusi kelompok secara sederhana, berbeda dengan metode yang diterapkan pada kelas eksperimen yaitu Guided Inquiry yang mendorong siswa untuk terlibat lebih aktif.

Selanjutnya untuk membuktikan apakah ada perbedaan yang signifikan antara aktivitas belajar siswa kelas eksperimen dengan kelas kontrol yaitu diuji secara statistik menggunakan uji two independent sample Kolmogorov-Smitnov dengan bantuan program SPSS I7.0 for Windows. Hasil uji tersebut dapat dilihat pada tabel 3 berikut ini.

Tabel 3. Hasil Uji Two Independent Sample Kolmogorov-Smirnov

\section{Test Statistics}

\begin{tabular}{llr}
\hline & & Aktivitas \\
Most & Absolajar \\
Extreme & Positive & .969 \\
Differences & Negative & .000 \\
Kolmogorov-Smirnov Z & -.969 \\
Asymp. Sig. (2-tailed) & 3.875 \\
\hline
\end{tabular}

Berdasarkan tabel 3 di atas dapat diketahui bahwa hasil uji Two Independent Samples KolmogorovSmirnov data aktivitas belajar siswa mempunyai nilai $\mathrm{p}$ (Asymp. Sig. 2-tailed) 0,000 lebih kecil dari 0,0I (p > $0,0 \mathrm{I}$ ). Hal ini berarti terdapat perbedaan yang sangat signifikan antara aktivitas kelas eksperimen dibandingkan dengan kelas kontrol.

\section{B. Hasil Belajar Siswa}

Pada penelitian ini dilakukan tes hasil belajar berupa pretest dan postest. Hasil tes yang telah dilakukan baik di kelas eksperimen maupun di kelas kontrol dapat dilihat pada tabel 4 dan gambar 4 di bawah ini.

Tabel 4. Hasil Tes Kelas Eksperimen dan Kontrol

\begin{tabular}{|c|c|c|c|c|c|}
\hline \multirow[t]{2}{*}{ No. } & \multirow[t]{2}{*}{ Statistik } & \multicolumn{2}{|c|}{ Eksperimen } & \multicolumn{2}{|c|}{ Kontrol } \\
\hline & & Pre. & Post. & Pre. & Post. \\
\hline I. & Jml. Siswa & 32 & 32 & 32 & 32 \\
\hline 2. & $\begin{array}{l}\text { Nilai } \\
\text { Terendah }\end{array}$ & 40 & 75 & 40 & 75 \\
\hline 3. & $\begin{array}{l}\text { Nilai } \\
\text { Tertinggi }\end{array}$ & 80 & 100 & 80 & 100 \\
\hline 4. & Rerata & 64.90 & 89.37 & 60.15 & 87.65 \\
\hline
\end{tabular}

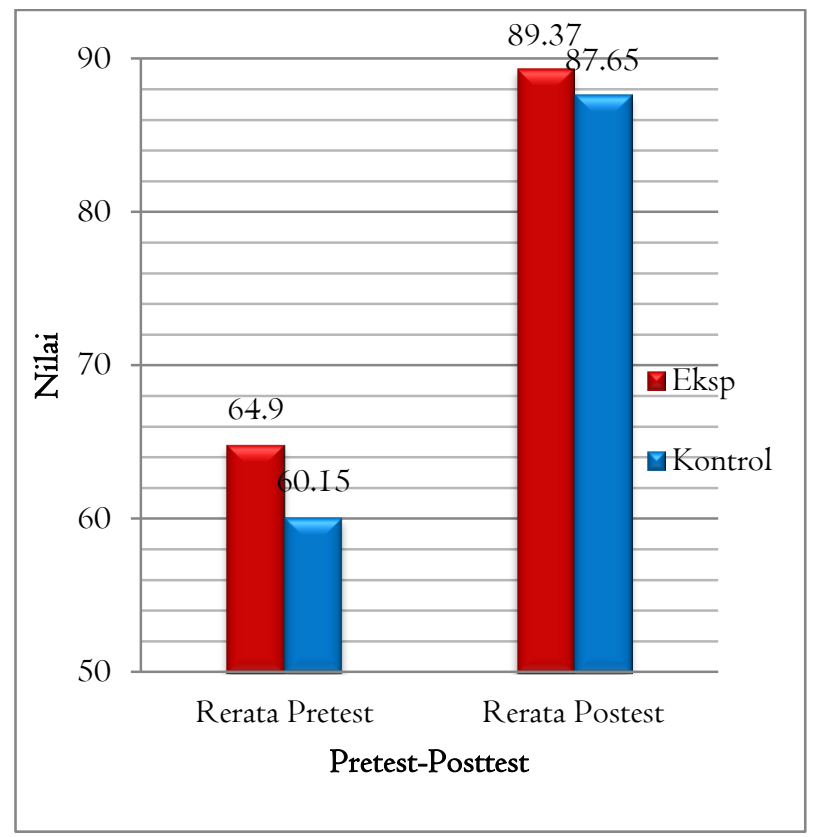

Gambar 3. Diagram Rerata Pretes dan Postes Kelas Kontrol dan Kelas Eksperimen

Hasil belajar biologi siswa dapat dilihat secara ringkas dan menyeluruh melalui data distribusi frekuensi pada gambar 4 dan 5 berikut ini.

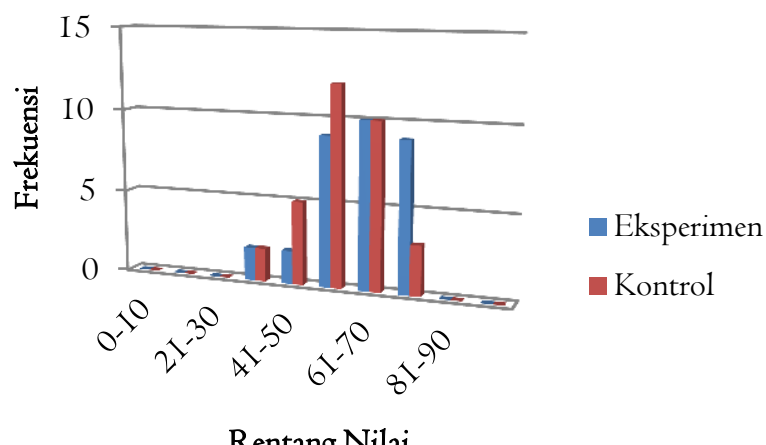

Gambar 4. Diagram Distribusi Frekuensi Nilai Pretest Kelas Eksperimen dan Kelas Kontrol

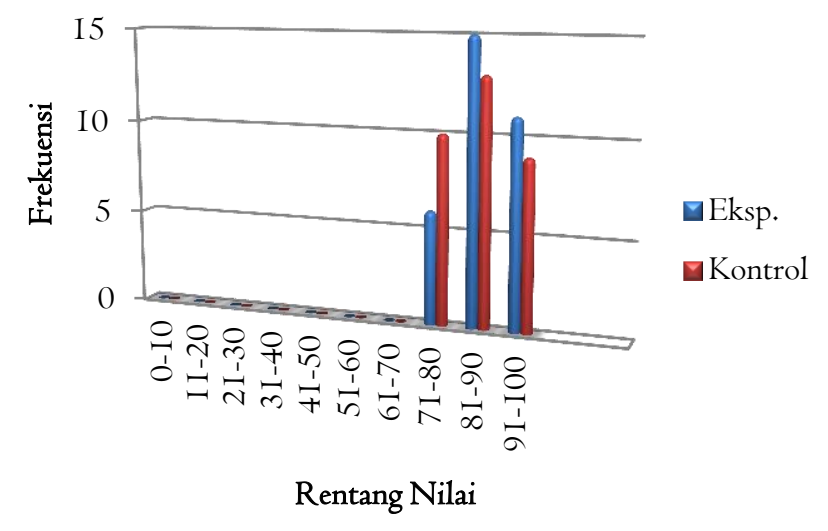

Gambar 5. Diagram Distribusi Frekuensi Nilai Posttest Kelas Eksperimen dan Kelas Kontrol 
Gambar 4 di atas menunjukkan bahwa persebaran nilai pretest terbanyak dari kelas eksperimen berada pada rentang nilai 6I-70, sedangkan kelas kontrol pada rentang 5I-60. Distribusi frekuensi nilai pretes pada kelas eksperimen dan kelas kontrol tersebut menunjukkan bahwa kedua kelas memiliki persebaran yang hampir sama. Sedangkan gambar 5 menunjukkan bahwa nilai posttest pada kelas eksperimen dan kelas kontrol memiliki persebaran nilai terbanyak berada pada rentang nilai 8I-90, hal ini menunjukkan bahwa nilai posttest baik kelas eksperimen maupun kelas kontrol sangat tinggi. Akan tetapi frekuensi siswa pada kelas eksperimen yang mendapatkan nilai tinggi lebih banyak dibandingkan kelas kontrol.

\section{Hasil Uji Pra-syarat}

Sebelum dilakukan uji hipotesis, terlebih dahulu dilakukan uji pra syarat untuk mengetahui normalitas dan homogenitas data. Uji normalitas data dilakukan dengan uji Chi-Square menggunakan program SPSS I7.0 for Windows. Uji normalitas bertujuan untuk mengetahui apakah distribusi dari masing-masing variabel normal apa tidak. Hasil uji normalitas data dapat dilihat pada tabel 4 berikut ini.

Tabel 4. Rangkuman Hasil Uji Normalitas

\begin{tabular}{|c|c|c|}
\hline No. Kelas & $\begin{array}{l}\text { Jenis } \\
\text { Data }\end{array}$ & $\begin{array}{c}\text { Taraf } \\
\text { signifikasi }\end{array}$ \\
\hline
\end{tabular}

\begin{tabular}{llcrl}
\hline I. & Eksperimen & Aktivitas & 0,05 & Normal \\
2. & Kontrol & Aktivitas & 0,05 & Normal \\
3. & Eksperimen & Pretest & 0,05 & Normal \\
& & Posttest & 0,05 & Normal \\
4. & \multirow{2}{*}{ Kontrol } & Pretest & 0,05 & Normal \\
& & Posttest & 0,05 & Normal \\
\hline
\end{tabular}

Berdasarkan tabel 4 di atas dapat diketahui bahwa hasil uji normalitas data lembar observasi aktivitas belajar siswa maupun data pretest dan posttest semuanya mempunyai nilai p (Asymp. Sig. (2-tailed) lebih besar dari $0,05(p>0,05)$. Hal ini berarti sebaran data penelitian berdistribusi normal.

Uji homogenitas dilakukan dengan uji-F menggunakan program SPSS I7.0 for Windows. Uji homogenitas dilakukan untuk mengetahui apakah dua kelas yang sedang diuji yaitu kelas eksperimen dan kelas kontrol mempunyai variansi yang sama atau tidak. Rangkuman hasil uji homogenitas terhadap data aktivitas dan hasil belajar siswa dapat dilihat pada tabel 5 berikut ini.

Tabel 5. Rangkuman Hasil Uji Homogenitas

\begin{tabular}{llcl}
\hline No. & $\begin{array}{c}\text { Jenis } \\
\text { Data }\end{array}$ & $\begin{array}{c}\text { Taraf } \\
\text { Signifikasi }\end{array}$ & Distribusi \\
\hline I. & Aktivitas & 0,05 & Homogen \\
2. & Pretest & 0,05 & Homogen \\
3. & Posttest & 0,05 & Homogen \\
\hline
\end{tabular}

Berdasarkan tabel 5 tersebut dapat diketahui bahwa hasil uji homogenitas data aktivitas maupun pretest dan posttest mempunyai nilai p (Asymp. Sig. 2-tailed) lebih besar dari 0,05 $(\mathrm{p}>0,05)$. Hal ini berarti sebaran data penelitian berdistribusi homogen.

\section{Hasil Uji Hipotesis}

Signifikansi atau perbedaan aktivitas belajar biologi antara kelas eksperimen dengan kelas kontrol dapat diketahui dengan menggunakan uji Two Independent Samples Kolmogorov-Smirnov. Berikut ini adalah tabel 6 hasil pengujian $T_{w o}$ Independent Samples Kolmogorov-Smirnov dengan bantuan program SPSS I7.0 for Windows.

Tabel 6. Hasil Uji Two Independent Samples Kolmogorov-Smirnov

\section{Test Statistics}

\begin{tabular}{llr}
\hline & & Aktivitas Belajar \\
Most & Absolute & .969 \\
Extreme & Positive & .000 \\
Differences & Negative & -.969 \\
Kolmogorov-Smirnov Z & 3.875 \\
Asymp. Sig. (2-tailed) & .000 \\
\hline
\end{tabular}

Berdasarkan tabel 6 di atas dapat diketahui bahwa hasil uji Two Independent Samples KolmogorovSmirnov data aktivitas mempunyai nilai p (Asymp. Sig. 2-tailed) 0,000 lebih kecil dari 0,0I ( $\mathrm{p}>0,0 \mathrm{I})$. Hal ini berarti terdapat perbedaan yang sangat signifikan antara aktivitas kelas eksperimen dibandingkan degan kelas kontrol.

Pengujian hipotesis hasil belajar siswa dengan menggunakan uji-t karena sampel pada penelitian ini hanya ada dua macam yaitu kelas eksperimen dan kelas kontrol. Uji-t dilakukan dengan bantuan program SPSS I7.0 for Windows. Uji-t dilakukan setelah melewati uji prasyarat yaitu uji normalitas dan uji homogenitas. Berdasarkan keterangan dari data-data uji pra-syarat yang telah dilakukan, maka data yang akan diuji-t ini sudah layak untuk dilakukan karena telah memenuhi kriteria yaitu distribusi datanya normal dan homogen.

Dalam melakukan uji-t, data yang dihitung diambil dari data hasil belajar siswa melalui posttest untuk kelas eksperimen dan kelas kontrol. Rangkuman hasil uji-t terhadap kelas eksperimen dan kelas kontrol dapat dilihat pada tabel 7 berikut ini.

Tabel 7. Hasil Uji-t Hasil Belajar Biologi Siswa

\begin{tabular}{llccc}
\hline \multicolumn{1}{c}{ Jenis } & Kelas & Mean & St. Deviasi & Sig. \\
\hline Hasil & Eksp. & 89.38 & 6.568 & 0.318 \\
belajar & kontrol & 87.66 & 7.069 & 0.318 \\
\hline
\end{tabular}

Syarat uji-t yang mempunyai perbedaan signifikan adalah jika nilai p (Sig.) lebih kecil dari 0,05. Berdasarkan tabel 7 di atas menunjukkan bahwa hasil 
belajar siswa mempunyai nilai $\mathrm{p}=0,3 \mathrm{I} 8(>0,05)$ yang berarti tidak terdapat pengaruh yang signifikan meskipun nilai rerata posttest kelas eksperimen $(89,38)$ lebih tinggi daripada nilai rerata kelas kontrol $(87,66)$.

Perbedaan hasil belajar yang tidak signifikan tersebut dipengaruhi oleh beberapa hambatan dalam menerapkan metode Guided Inquiry di dalam kelas eksperimen. Hambatan-hambatan tersebut yaitu, Pertama, metode Guided Inquiry merupakan metode pembelajaran yang menekankan pada dua aspek yang sama pentingnya, yaitu proses belajar dan hasil belajar. Selama ini pembelajaran yang sudah terbiasa dengan pola pembelajaran sebagai proses menyampaikan informasi lebih menekankan pada hasil belajar, bukan pada prosesnya, sehingga agak sulit untuk mengubah pola mengajarnya.

Kedua, sudah sejak lama tertanam dalam budaya belajar siswa bahwa belajar pada dasarnya adalah menerima materi pelajaran dari guru, dengan demikian bagi mereka guru adalah sumber belajar yang paling utama. Karena budaya belajar seperti itu sudah terbentuk dan menjadi kebiasaan, maka agak sulit untuk mengubah pola belajar mereka dengan menjadikan belajar sebagai suatu proses berpikir. Siswa menjadi kesulitan apabila diajak memecahkan suatu persoalan, mengajukan pertanyaan, ataupun menjawab pertanyaan.

Ketiga, terbatasnya kemampuan dan pengalaman peneliti dalam menerapkan metode pembelajaran, baik di kelas eksperimen maupun kelas kontrol. Menurut Sanjaya (2010: 207), untuk menjadi seorang guru yang baik diperlukan kemampuan yang tinggi dalam mengajar dan pengalaman yang luas, sehingga mampu mengatasi setiap hambatan yang terjadi di lapangan. Kondisi siswa yang terlalu aktif, terlalu pasif, lambat dalam memahami pelajaran, suka menyontek saat diadakan test, dan lain sebagainya, merupakan suatu kondisi yang memerlukan penanganan khusus.

Metode Guided Inquiry dalam penelitian ini memang tidak memberikan pengaruh yang signifikan terhadap hasil belajar, akan tetapi metode ini memberikan pengaruh yang sangat signifikan terhadap aktivitas belajar siswa. Oleh karena itu, metode Guided Inquiry sangat dianjurkan untuk diterapkan karena memiliki beberapa keunggulan yaitu:

I. Merupakan metode pembelajaran yang menekankan pada pengembangan aspek kognitif, afektif, dan psikomotor secara seimbang, sehingga pembelajaran melalui metode ini lebih bermakna.

2. Dapat memberikan lebih banyak ruang kepada siswa untuk belajar sesuai dengan gaya belajar mereka.

3. Merupakan metode yang sesuai dengan perkembangan psikologi belajar modern yang menganggap belajar adalah proses perubahan tingkah laku berkat adanya pengalaman.

4. Dapat melayani kebutuhan siswa yang memiliki kemampuan diats rata-rata.
Di samping memiliki keunggulan, menurut Sanjaya (2010: 207-209), metode Guided Inquiry juga memiliki kelemahan, diantaranya yaitu:

I. Sulit dalam menerapkan karena terbentur dengan kebiasaan belajar siswa yang cenderung konvensional.

2. Memerlukan waktu yang lebih lama sehingga sulit dalam menyesuaikan dengan jadwal yang sudah ada.

3. Selama kriteria keberhasilan belajar ditentukan oleh kemampuan siswa dalam menguasai materi pelajaran, maka metode Guided Inquiry sulit diterapkan oleh setiap guru.

Memang pada dasarnya tidak ada suatu metode pembelajaran yang benar-benar sempurna. Setiap metode mempunyai kelebihan dan kekurangan masing-masing. Oleh karena itu seorang guru harus bisa menentukan suatu metode yang paling tepat, sekaligus mengatasi kekurangan-kekurangan yang ada, dan mempertahankan kelebihan yang dimiliki suatu metode tersebut. Namun, tidak ada salahnya bagi seorang guru untuk berani mencoba metode-metode pembelajaran yang lebih variatif agar siswa tidak mudah bosan sehingga diharapkan bisa meningkatkan hasil belajar mereka.

\section{Simpulan}

Berdasarkan hasil penelitian tentang pengaruh penerapan metode Guided Inquiry terhadap aktivitas dan hasil belajar biologi pada materi avertebrata siswa kelas X SMA Negeri 2 Banguntapan tahun ajaran 2010/20II dapat ditarik kesimpulan sebagai berikut:

I. Terdapat pengaruh yang sangat signifikan $(\mathrm{p}<$ 0,OI) terhadap aktivitas belajar siswa dengan menerapkan metode Guided Inquiry. Hal ini ditunjukkan dan dibuktikan dengan hasil uji Two Independent Samples Kolmogorov-Smirnov, dengan nilai $\mathrm{p}=0,000$.

2. Tidak terdapat pengaruh yang signifikan $(\mathrm{p}>$ $0,05)$ terhadap hasil belajar biologi siswa dengan menerapkan metode Guided Inquiry. Hal ini ditunjukkan dan dibuktikan dengan hasil uji-t, dengan nilai $\mathrm{p}=0,3 \mathrm{I}$.

\section{Daftar Pustaka}

Anas Sudijono. (2003). Pengantar Statistik Pendidikan. Jakarta: Raja Grafindo Persada

B. Suryosubroto. (2009). Proses Belajar Mengajar di Sekolah. Jakarta: Rineka Cipta

C. Trihendradi. (2009). 7 Langkah Mudah Melakukan Analisis Statistik Menggunakan SPSS I7. Yogyakarta: Andi Offset

KBBI (Kamus Besar Bahasa Indonesia) versi digital, download di http://www.ebsoft.web.id I5:I2 PM 03/08/2008 
Nana Sudjana. (1989). Dasar-Dasar Proses Belajar Mengajar. Bandung: Sinar Baru

Nana Sudjana. (2009). Penilaian Hasil Proses Belajar Mengajar. Bandung: Remaja Rosdakarya

Nurul Zuriah. (2006). Metodologi Penelitian Sosial dan Pendidikan. Jakarta: Bumi Aksara

Sardiman A. M. (2010). Interaksi dan Motivasi Belajat Mengajar. Jakarta: Raja Grafindo Persada

Sugiyono. (2010). Metode Penelitian Pendidikan Pendekatan Kuantitatif, Kualitatif, dan R\&D. Bandung: Alfabeta

Syaiful Sagala. (2010). Konsep Dan Makna Pembelajaran. Bandung: Alfabeta

W. Gulo. (2008). Strategi Belajar Mengajar. Jakarta: Gramedia

Wina Sanjaya. (2010). Strategi Pembelajaran Berorientasi Standar Proses Pendidikan. Jakarta: Kencana 